\title{
RISIKO RADIASI DARI COMPUTED TOMOGRAPHY PADA ANAK
}

\author{
Zubaidah Alatas \\ Pusat Teknologi Keselamatan dan Metrologi Radiasi-BATAN \\ Jl, Lebak Bulus Raya 49, Jakarta Selatan \\ Emat: zalatas@batan.go.id
}

\begin{abstract}
ABSTRAK
RISIKO RADIASI DARI COMPUTED TOMOGRAPHY PADA ANAK. Compute' Tomography (CT) adalah test medik non invasif yang digunakan uatuk deicksi. diagnostik dan menindak penyakit, CT' merupakan kombinasi antara surnber sinar $\mathrm{x}$ dan sistem komputerisasi yang eanggih untak menghasilkan sejumlah eitrd atau grambar tentang kondisi interial tubuh. Sejak pernenalan C'T pada tahun 1970an, pengyutiannya meningkat secara cepat. Berdasarkan sifatnya, (T melibatkan tingkat paparan dosis radiasi pengion yarig lebih besar dibandingkan dengan prosedur pencitraan sinar-x konvensional. Dosis efektif radtási dan prosedur ini berkisar dari 5 sampai $100 \mathrm{mSv}$, karang lebih sama dengan rerata manusia metseruma paparan radiasi alam selama 8 bulan sampai 3 tahtm. Terdapat bukti epidemiologik yang kécil tetapi signifikan terhadap peningkatan risiko kanker akibat dosis radiasi dari tindakan CT. Karena arak-anak lebih sensitif terhadap radiasi, maka pengguriaan CT pada anals hanya jika sangat penting dalam membuat kepurusan diagrostik dan tidak dilakukan pengulangan kecuali jika sangat diperlukars. Meskipun risiko indrvidnal terhadap kanker tidak besar_tetapi peningkatati paparan radiasi dalam populasi berpotensi menjadt isu keselkatan masyarakat di maka datang. Makalah ini membahas sifat dan aplikısi utama CT sehagai alat diagnostik, dosis radiasibya, risiho kanker pada anak sebagai isu kesehatan masyarakat, dan upaya untuk mengurangi dosis radiasi CT padi anak Informasi dalam makalah ini diharapkan untuk membantu dalam pengambilan kepulusan dan diskusi dengan lin medik, pasien dan keluarga.
\end{abstract}

Kata kunci ; Computed tomograph, anak, pencitran diaguostik, sadiasi pergion, kanker

\section{ABSTRACT}

RISK OF RIDIATION FROM COMPUTED TOMOGRAPHY ON CHILDREN, Camputed Tomography $(C T)$ is a noninvasive medical rest that is used fo detect diagnose and freat diveases. CT rombines special $x$-raty equipment uith sophisticated computers to produce madtipte images or picture's of the inside of the body. Since the inception of CT we the 1970s, its trse has increased rapidly, By its nature, CT mwolves larger radiation doses that the more common. convehtival $x$-ris imaging procedwos, The effective dose from this procedure is approximately fram 5 to $160 \mathrm{~m}$ Su which is comparable to the exposure of nataral rudiation for about 8 months to 3 vears. There is epideminlogical vividince of a small bu significant

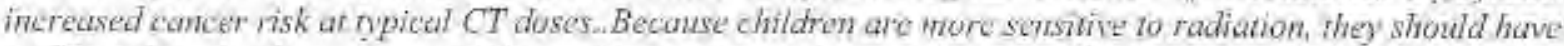
a CT study ondy if it is essential for making a diagnosis and should nor have repeated CT stucties unless

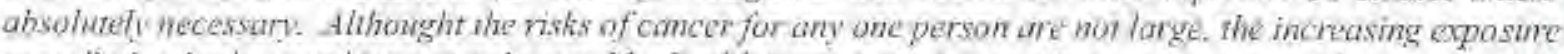

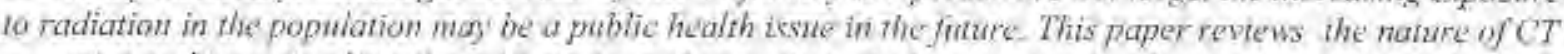
scamning and its main clinic al applications as diagnostic fool the associated radiation doses, the consequent cimcer risks in chilaten as the issue of public health, and the efforts to reduce the doses of pediatric CT. The information in this paper is expected ro uid in decision-matang and discassions with the beulth care tetam, patients und fumülies:

Key Words: computed tomography: children, diagnostic imaging tätzing rudiation, canver

\section{PENDAHULUAN}

Computed Tomography (CT) adalah alat diagnostik menggunakan sinar- $X$ yang dapat memberikan informasi visual secara rinci dan akurat tentang kondisi sistem organ intemal tubuh. Ilasil pencitraan crosssectional bagian dari organ target dâpat diamati secara seksama pada monitor komputer dan dicetak atau ditransfer ke dalam CD. Pemeriksaan dengan CT skan pada organ 
dalam Lubuh, tulang, jaringan lunak dan pembuluh darah memberikan informasi yang jauh lebih baik dan lengkap dibandingkan pemeriksaan dengan sinar-x konvensional. Dengan peralatan canggih ini dàn keahlian khusus untuk memperoleh dan menginterpretasi hasil CT skan tubub, para radiologist dapat dengan lebih mudah mendiagnosa penyakit khususnya kanker, penyakit jantung dan pembuluh darah. penyakit infeksi, apendiks, trauma dan kelainan musculoskeleta! !n!

Telah terjadi peningkatan tajam penggunaan CT skan untuk keperluan diagnostik pada anak ${ }^{12 / 3)}$ dan skrining pada orang dewasa yang cenderung akan terus berlangsung ${ }^{[0]}$ pada beberapa tahun yang akan datang. Kekawatiran tímbul karena sekali tindakan CT skan akan memberikan paparan tadiasi pada organ target dengan dosis mencapai 190 kali lebih besat dari tindakan radiologi konvensional seperti foto rontgen. Dalam implementasinya pada anak, prosedur CT skan sangat bermanfaat untuk mendiagnosa penyakit dan luka pada anak, khususnya limfoma, neuroblastoma, kelainan bawaan pada pembulula darah, dan ginjal ${ }^{2\}}$ ?

Peningkatan dalam penggunaan teknik pencitraan CT skan pada anak berpotensi pula peningkatkan paparan radiasi padi anak yang menyebabkan tindakan CT pada anak menjadi perhatian khususnya terkait kesehatan masyarakat. Faktor yang membuat CI skan menjadi pusat perhatian adalah (1) lingkat paparan radiasi lebih tinggi dari pencitratan diagnostik lainnya, (2) penggunaan yang meningkat cepat. (3) penggunaan parameter yang sama dalam prosedur CT skan baik untuk anak maupun orang dewasa, dan (4) potensi risiko kanket, Besaran energi radiasi yang terima setiap organ pada tindakan CT skan dinyatakan dosis serab (Gy) yang menggambarkan jumlah energi (Joule) yang diterima per massa jaringan/organ tubuh $(\mathrm{Kg})$. Ketika mencakup dosis radiasi pada beberapa organ yang terlibat dalam lindakan CT skan. dosis efektil (Sv) yang digunakan untuk kuntifikasi risiko pada pasien. International Committee on Radiological Pratection (ICRP) menyataan bahwa dosis serab pada jaringan tubuh dari tindakan CT skan sering mendekati atau melampaui tingkat yang diketahu berpotensi meningkatkan probabilitas terbentuknya kanker ${ }^{169}$.
Makalah ini membahas sifat dan aplikasi utama CT sebagai alat diagnostik, tingkat paparan radiasi pada penggunaan CT skan pada anak dan konsekuensinya berupa indoksi kanker yang berpotensi sebagai masalah kesehatan masyarakat, dan upaya untuk mereduksi dosis radiasi CT pada anakanak. Sangat diharapkan informasi ini dapat membantu dalam inisiasi dialog attara tim medik dengan pasien dan keluarga terkait dengan keseimbangan manfast dan rísiko dari penggunaan CT skan pada anak.

\section{Computed Tomography - Pemanfaatannya}

Peralatan CT scamer berupa mesin berbentuk kotak besar dengan sebuah lobang atau terowongan pendek pada bagian tenganya. Pasien akan berbaring di atas meja pemeriksaan yang sempit. Di sekeliling tubuln pasien ferdapat tabung sinar-X yang berotasi dan detektor sinar-X terdapat pada posisi yang berlawanan dalim sébuah cincin yang disebut ganny. Sistem komputerisasi memproses informast pencitran terdapat dalam ruangan yang terpisah. ketika teknologist mengoperasikan CT scanner dan memozitor proses pemeriksaan pasien. Pada pemeriksaan dengan sinar- $X$ konvenssonal, sebuah hamburan kecil radiasi ditujukan pada tubuh pasien dan citra yang terbentuk direkam pada film fotografik atau tempat rekaman khusus lainnya. Pada film, struktur tulang akan nampak patih jaringan lunak berupa bayangan abu-abu, dan udara nampak berwama hitam. Pada prosedur CT scanner, sejumlah besar hamburan sinar-X dan pengaturan elektronik detektor sinar- $\mathrm{X}$ berotasi pada selurula tubub pasien untuk mengukur jumlah radiasi yang diserab seluruh tubuh pasien ${ }^{27}$.

Prinsip dasar axial dan twelical (spiral) scanning $\mathrm{CT}$ seperti yang ditunjukkan pada Gambar 1 adalah sebagai berikut. Sebuah meja bermolor menggerakkan pasien melewati sistem pencitraan CT. Pada saat yang bersamaan, sebuah sumber sinar-X berotasi dalam pembukaan sirkular, dan stau set detektor sinar- $\mathrm{X}$ berotasi secara selaras pada sisi lain dari tubuh pasien. Sumber sinar- $X$ menghasilkan pancaran radiasi berbeniuk kipas dengan lebar antara 1 sampai $20 \mathrm{~mm}$. Pada CT uxial yang umumnya digunakan untuk skan kepala, meja berada pada posisi statis sclama rotasi, yang kemudian terus digerakkan untuk 
Slice berikutnya. Pada CT helieal yang umumnya digunakan unituk skan tubuh. meja bergerak secara kontinyu bersamaan dengan dengan sumber sinar-X dan detektor berotasi untuk menghasilkan sebuah skan spiral. Ilustrasi imi menunjukkan sebuah rangkaian runggal detektor meskipun sesungguhriya mesin umumnya memiliki rangkaian sejumlah detektor yang beroperasi secara beryantian (side by side). sehingga beberapa slice (dapat mencapai 64 buah) dapat dicitrakan secara simultan yang mereduksi waktu total scanning. Semua data diprosiss oleh komputer untuk menghasilkan satu seri citra dalam bentuk slice tiga dimensi dari organ atau bagian tubuh yang menjadi target ${ }^{[7]}$.

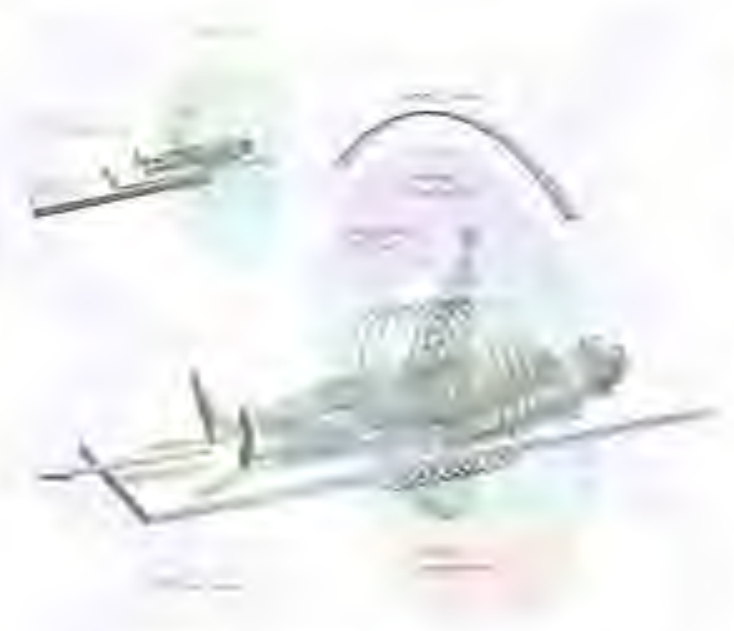

Gambar 1. Prinsip dasar dari $C T^{|7|}$

CT scamner yang modern dapat melakukan skan selurub bagian tubuh dengan sangat cepat. hanya dalam beberapa detik. Kecepatan tinggi seperti ini sangat bermatufaat unnuk semua pasien khususnya anak-anak. pasien lanjut usia, dan pasien sakit parah. Untuk anak-anak, teknik CT scammer dapat disesuaikan untuk mereduksi dosis radiasi. Untuk beberapa pemeriksaan CT skan, bahan kontras digunakan untuk meningkatkan visibilitas bagian tubuh yang menjadi target pemeriksaan. Pemeriksaan dengan CT skan tidak menimbulkan rasa sakit, tidak infasif, cepat, sederhana, dan akurat dengan keutamaan memberikan sejumlah citra yang rinci tentang kondisi organ target di saat yang bersamaan. Pada kondisi emergensi, pemeriksaan ini dapat menunjukkan kerusakan dan pendarahan internal dengan cukup cepat dalam rangka melakukan penyelamatan hidup pasien. Tidak seperti duggnostik sinar-x konvensional, tindakan CT skan sering digunakan untuk identifikasi kerusakan pada paru, jantung dar pembuluh darah, hati, limfa, ginjal, dan organ pencernaan secara cepat; untuk merencanakan dan mengkaji keberhasilan tindakan operasi: untuk mengetahui stadium kanker sebagai dasar pertimbangan pemberian tindakan radioterapi; untuk memantau respon tindakan kemoterapi; untuk mengukur densitas mineral dalam tulang untuk deteksi osteoporosis; dan lainnya ${ }^{[7]}$.

Penggunaan CT dapat dikategorikan berdasarkan tujuan pencitraan yang dilakukan yaitu untuk diagnosis pada pasjen simptomatik atau untuk skrining pasien usimptomatik. Peningkatan terbesar dari penggunaan $\mathrm{CT}$ skan untuk dewasa adalah untuk pasien asimptomatik dengan aplikasi paling banyak untuk skrining colon polyp ivirtual colonoseopy) ${ }^{[8][5]}$. kanker pani tahap awal pada perokok dan mantan perokok perpor, penyakit jantung $\Gamma$ dan seluruh tubuh Irij[ial] Penggunaan utama CT pada anak adalah untuk diagnosis apendiks yang lebih akurat dan efektif sebelum tindakan operasi dilakukan ${ }^{[13]}$ Peningkatan dalam penggunaan CT pada snak terutama disebabkan oleh sedikitnya waktu yaing dibutuhkan untuk melaksanakan sekali skan yaitu kurang dari I detik dan tidak membutuhkan tindakan anastesi untuk mencegah seorang anak bergerak selama proses pemeriksaan berlangsung ${ }^{\text {T2I }}$.

\section{Tingkat Radiasi Pada Organ Dalam Pemeriksaan Dengan $\mathrm{Ct}$ Scan}

Perbandingan dosis radiasi yang diterima organ target dari beberapa metode pemeriksaan radiologik ditunjukkan pada Tabel 1. Terlihat bahwa dosis tipikal untuk paru dengan sinar- $X$ paru korivensional antara $0.01 \mathrm{mGy}$ sampai $0.15 \mathrm{mGy}$, sementara dosis. tipikal pada organ vang diperiksa dengan CT adalah sekirar $10 \mathrm{mGy}$ sampai $20 \mathrm{mGy}$,dan dapat mencapat $80 \mathrm{mGy}$ untuk 64 slices pemeriksaan CT coronary angiography ${ }^{\text {i1) }}$

Pada findakan CT skan yang paling umum, besaran dosis radiasi yang diterima organ target dari sekali pemeriksaan dengan CT skan difunjukkan pada Gambar 2 di bawah ini dengan setling mesir yang umum digunakan untuk skan area kepala dengan organ utama otak dan area abdomen dengan organ utama sistem pencernaan ${ }^{[7]}$. 
Tabel 1. Perkiraan besaran dosis yang diterima organ utama pada berbagai pemeriksaan

\begin{tabular}{|c|c|c|}
\hline $\begin{array}{c}\text { Jenis } \\
\text { pemeriksaaan }\end{array}$ & $\begin{array}{l}\text { Organ } \\
\text { terkait }\end{array}$ & $\begin{array}{c}\text { Dosis organ } \\
\text { terkait } \\
\text { (mGy atau } \\
\text { mSy) }\end{array}$ \\
\hline $\mathrm{X}$-ray gigi & Otak & 0,005 \\
\hline X-ray dada PA & Paru & 0.01 \\
\hline $\begin{array}{l}\text { X-ray dada } \\
\text { lateral }\end{array}$ & Paru & 0.15 \\
\hline Mamografi & Payudara & 3 \\
\hline $\begin{array}{l}\mathrm{CT} \text { abdomen } \\
\text { dewasa }\end{array}$ & Lambung & 10 \\
\hline $\begin{array}{l}\mathrm{CT} \text { abdomen } \\
\text { bayi }\end{array}$ & Lambung & 20 \\
\hline $\begin{array}{l}\text { CT angiografi } \\
\text { koroner }\end{array}$ & Paru & $40-100$ \\
\hline
\end{tabular}

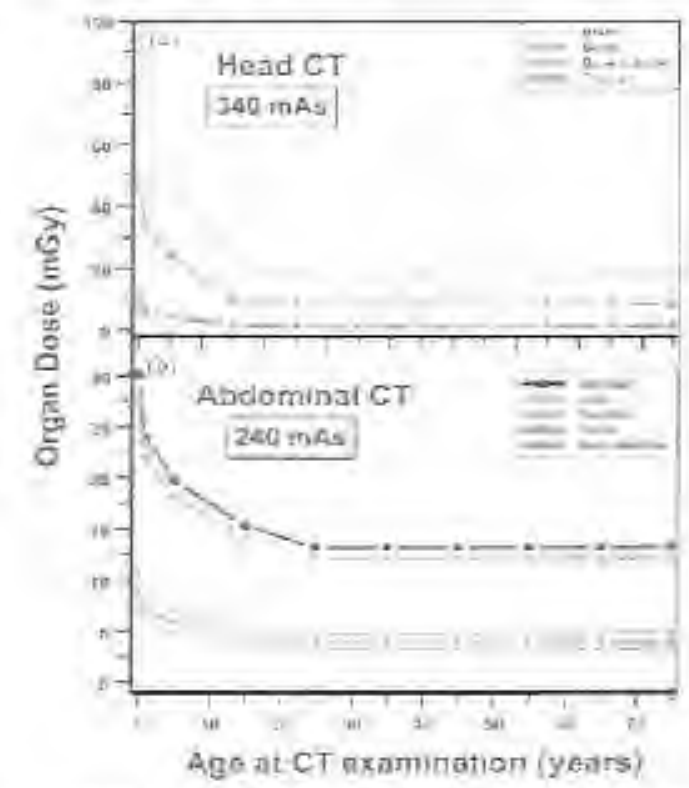

Gambar 2. Perkiraln dosis organ (mGy) dari standar CT skan tunggal pada (a) kepala dan

(b) abdomen sebagai fungsi usia saat pemeriksaan $^{[7]}$

Tingkat paparan radiasi pada organ target dalam pemeriksaàn dengan CT skan terutama berganumg pada jumlah skan, produk arus tabung dan waktu skan (mAs), ukuran tubuh pasien, rentang axial scan, scan pitch (tingkat overlap antara slice yang berdekatan), maksimum voltase tabung $(\mathrm{kVp})$ dan desain scamner tertentu ${ }^{115}$. Dosis radiasi yang diterima organ tubuh terutama bergantung pada jumlah skan dan milliamp-seconds ( $\mathrm{m} / \mathrm{s}$ ) setting 11!. Sebagian dari parameter ini dapat disesuaikan dengan jenis perneriksaan dan ukuran tubuh pasien. Untuk pengaturan mAs tertentu. dosis pada anak jauh lebih besar dari dosis dewasa karena torso anak yang lebih tipis memberikan penahan/tabir lebil kecil terhadap paparan radiasi pada organ. Pengurangan mAs untuk keperluan pemeriksaán pada anak secara proporsional dapat mereduksi dosis radiasi pada anak (tetapi kenyataannya sering tidak dilakukan. Tindakan reduksi ini memperkecil

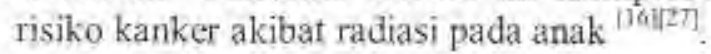

\section{Risiko Radiasi Dari Pencitraan Diagnostik Ct Scan}

Paparan radiasi pengion pada materi biologik umumnya menginisiasi pembentukan radikal bebas hidroksil sebagai hasil interaksi radiasi dengan molekul air, Radikal bebas ini akan berinteraksi dengan molekul DNA terdekat dan menyebabkan kerusakan pada ikatan dan struktur penyusun DNA yaitu berupa kerusakan pada basa nitrogen (seperti pirimidin dimer) dan kerusakan pada struktur molekul gula dan fosfat yang mengakibatkan putusnya strand DNA (single strand breah dan double strand breaks). Sinar-x dapat mengionisasi DNA baik secara langsung maupun tidak langsung melalui pembentukan radikal bebas tersebut di atas. Sebagian besar kerusakan DNA dapat dengan cepat mengalami proses perbaikan dengan berbagai sistem perbaikan enzimatis DNA di dalam sel. Kerusakan DNA double strand breaks merupakan kerusakan paling sulit untuk diperbaiki dan berpotensi menimbulkan kesalahan dalam proses perbaikan yang akhirnya dapat mengarah pada induksi mutasi titik dan aberasi kromosom yang semuanya sangat berpotensi dalam menginisiasi proses pembentukan kanker atau karsinogenesis radiasi ${ }^{i t s]}$.

CT scanners and peralatan pencilraan diagnostik lainnya menggunakan sumber radiasi dengan dosis rendah yang didefinisikan sebagai sebuah dosis yang kurang dari sekitar $100 \mathrm{mSv}$. Pada paparar yang lebih tinggi, fisiko kanker meningkat secara linier dengan meningkatnya dosis sampai menyebabkan kematian sel terjudi pada paparan sangat tinggi. Hubungan antara paparan radiasi dan risiko kanker dari radiasi dosis rendah adalah kurang jelas ${ }^{[10]}$.

Potensi risiko kesehatan yang berhubungan dengan tindakan pemeriksaan 
dengan prosedur radiologi dosis tinggi dapat secara kuantitatif dikaji dengan beberapa cara. Satu pendekatan sedierhana menggunakan konsep dosis efektif sebagai nilai lunggal yang proporsional dengan tingkat kerusakan radiobiologik yang dapat berupa karsinogenesis, pemendekan masa hidup dán efek pewarisan Dosis efektif merupakan perjumlahan dari dosis ekuivalen terhadap radiosensitivitas sefiap organ/jaringan yang telah dikoreksi dengan faktor bobot jaringan berdasarkan spesifik jaringan. Dosis efektit umumnya digunakan dalam radiologi untuk memungkinkan dilakukan pembandingan risiko terkait distnbusi dosis radiasi yang berbeda yang dihasilkan oleh teknik pencitraan yang berbeda. Jika dosis efektif pada semua individu yang terlibat dijumlahkan, hasilnya adalah dosis kolektif. Jika dosis kolektif kemudian dikalikan dengan perkiraan risiko fatal kanker generik pada paparan seluruh tubuh. hasilnya adalah nerkiraan sangat kasat tentang jumlah kanker tatal yang dihasilkan dari prosedur ${ }^{\left[{ }^{[}\right]}$.

Pendekatan yang lain melalui studi epidemjologi skala besar tentang risiko kanker terkait dengan CT skan Akan tetapi studi im masih tahup awal dan belum memberikan hasil sampai beberapa uhun ke depan. Perkiraan risiko kanker terkait paparan radiasi dari penggunaan CT skan masih memungkinkan untuk dilakukan dengan mengukur atau menghitung dosis organ yang terlibat dan menerapkan data insiden atau mortalitas kanker spesifik organ yang telah diperoleh dari studi epidemiologi risiko kanker pada para korban bom atom Hiroshima dan Nagasaki.

Data dari korban bom atom merupakat gold standard dalam kajian kuantitatif risiko karsinogenesis radiasi dosis rendah yang terus dilakukan selama 60 tahun dan masih berlangsung sampai saat ini. Data dari kohort korban bom ini umumnya digunakan sebagai dasar untuk prediksi risiko terkait radiasi pada suatu populasi karena kohortnya besar, telah secara intensif dipelajari selama perjode beberapa dekade dan mencakup semua kelompok usia. Estimasi risiko katiker akibat dari Josis radiasi yang relevan dengan dosis dari CT skan adalah dari stodi pada sekjatar 30.000 korban bom atom yang bertahan hidup yang terpapar tadiasi dengan dosis sebanding dengan salu atau beberapa kali CT skan [16] Terdapat peningkatan nyata dalam keseluruhan risika kanker pada sub grup korban bom atom yang menerina radiasi dosis rendah antara 5

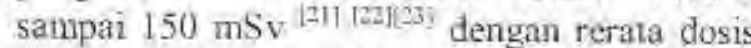
pada sub grup ini sekitar 40 tnSy, Nilai ini setara dengan dosis organ dari lipikal pemeriksaan dengar CT skan yang melibatkan dua atau liga skan pada dewasa. Dua kesimpulan utama dari studi epidemiologi pda korban bom atom adalah (1) risiko semua kanker solid konsisten dengan peningkatan limier dosis radiasi, đari dosis rendah sampai 2.5 Sv dan (2) anak-anak jauh Jebih radiosensitif dari pada deswasa.

Data risiko kanker bom atom dosis rendah konsisten dengan hasil studi epidemiologi skala besar pada 400,000 pekerja radiasi di industri nuklir ${ }^{525 i}$ yang terpapar radiasi dengan rerata sekilar $20 \mathrm{mSy}$. sebuah tipikal dosis organ dari sebuah C'1 skan lunggal pada dewasa. Hubungan yang stgnifikan dilaporkan antara dosis radiasi dan mortalitas dari kanker dalam kohort ini dengan peningkatan signifikan pada risiko kanker di antara para pekerja yang menerima dosis antara 5 dan $150 \mathrm{mSv}$. Bergantung pada setting sistem pađa CT seanher, organ target akan menerima đosis radiasi dalam kisaran $15 \mathrm{mSv}$ (pada dewasa) sampai $30 \mathrm{mSv}$ (pada bayi baru lahir) untuk CT skan tunggal yang umumnya dilakukan dua sampai tiga CI skan per pasien yang akhirnya dapat mencapal dosis dalam rentang 30 sampai $90 \mathrm{mS}$. Dengan demikian, pada rentang dosis tersebut, terbukti akan menga lami peningkatan risiko kanker ${ }^{[11}$, - Jika dikaitkan dengan usia, terdapat penurunan risiko kanker dari papam radiasi 10 mGy $(10$ mSv) dengan bertambahnya usia untuk sebagian besar kanker yang ditujukkan pada Gambar $3^{|a|}$

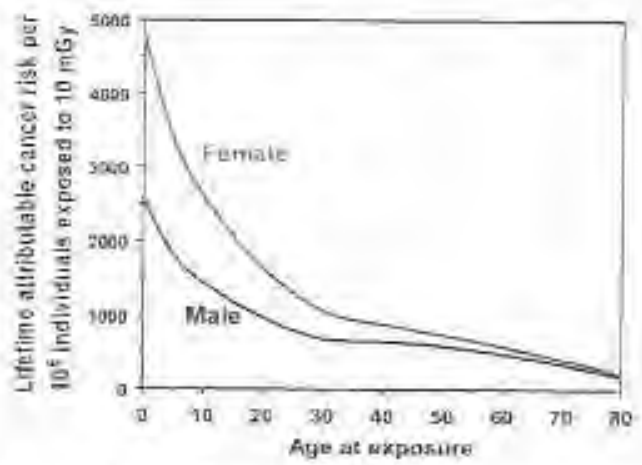

Gambar 3. P'erkiraan risiko masa hidup yang dapat ditandai (attributable) dari sebuah dosis tunggal dan kecil ( $10 \mathrm{mGy}$ ) sebagai fungsi dari usia pada saat terpapar ${ }^{[24}$ 


\section{Jurnal Forum Nuklir (JEN), Volume 8. Nomor 2, November 2014}

\begin{abstract}
Bukti ini secara beralasan menyakinkan untuk dewasa dan sangat menyakinkan untuk anak. Untuk sebuah dosis tertentu, terdapat perbedaan dalam risiko kanker dari paparan radiasi terhadap anak dibandingkan dengan dewasa. Beberapa alasatı untuk perbedaan ini adalah (1) sebagian besar jaringan dan organ pada anak dalam tahap pertumbuhan dan perkembangan yang menyebabkan menjadi lebih sensitif terhadap efek radiasi dibandingkan dengan organ orang dewasa yang sudah matang, dan (2) efek onkogenik radiasi mempunyai masa laten yang lama dan bervariasi bergantung jenis kanker. Leukemia mempunyai periode jebih singkat (sekitar 2-10 tahun) dari kanker mempat, Anak memiliki harapan hidup yang lebih panjang untuk memanifestasikan potensi efek onkogenik radiasi dibandingan dengan dewasa. Sebagai contol, sebuah kanker mempat yang diinduksi radiasi dengan 30 tahun periode laten akan lebih besar kemungkinannnya terjadi pada yang berusia 10 tahun dihandingkan dengan yang berusia 50 tahun. dengan dasar harapan hidup.
\end{abstract}

Gambar 4 menunjukkan dosis radiasi yang diterima beberapa organ pada area kepala dan abdomen dan risiko kematian akibat kanker dari tindakan tunggal CT skan. Panel A dan B pada gambar terscbut menunjukkan perkiraan tipikal dosis radiasi untuk organ pilihan sebagai fungsi usia saat skan dilakukan. Seperti yang diharapkan, otak menerima dosis paling besar selama CT skan di area kepala dan organ-organ pencernaan khususnya lambung akan menerima dosis paling besar selama $\mathrm{CT}$ skan di area abdomen. Panel C dan D menunjukkan perkiraan risiko kematian seumur hidup akibat kanker fatal ${ }^{[1]}$.

Seperti yang telah dibahas, dosis organ untuk tindakan CT skan yang melibatkan dua atau tiga skan untuk satu pemeriksaan, berada dalam kisaran adanya bukti statistik yang signifikan dalam meningkatkan risiko kanker. Oleh karena itu risiko terkait CT tertentu dapat dikaji secara langsung dari data epidemiologi. tanpa membutuhkan ekstrapolasi risiko yang diukur $\mathrm{ke}$ dosis rendah. Meskipun perkiraan risiko individual seperti yang ditunjukkan pada Gambar 4 adalah kecil, kekawatiran tentang risiko dari penggunaan $\mathrm{CT}$ skan dengan peningkatan yang cepat dant terus berlangsung, risiko individual yang kecil ini jika diaplikasikan secara meningkat ke populasi yang lebih besar akan menimbulkan masalah bagi kesehatan masyarakat pada beberapa tahun ke depan.

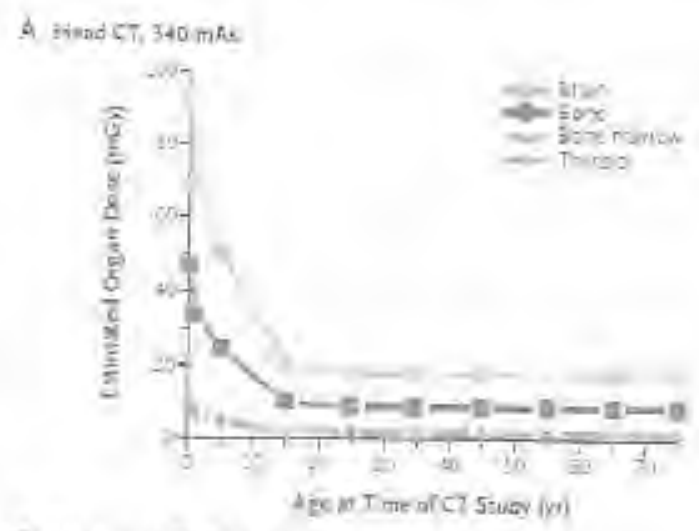

B abdominaiCT, 2ipmat

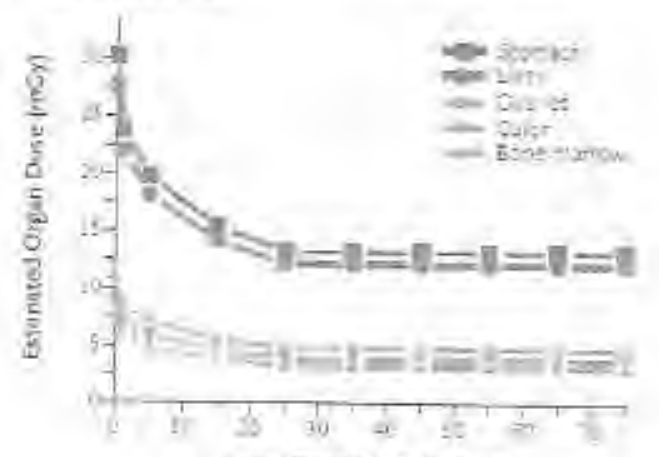

Deas CT. 340 ands

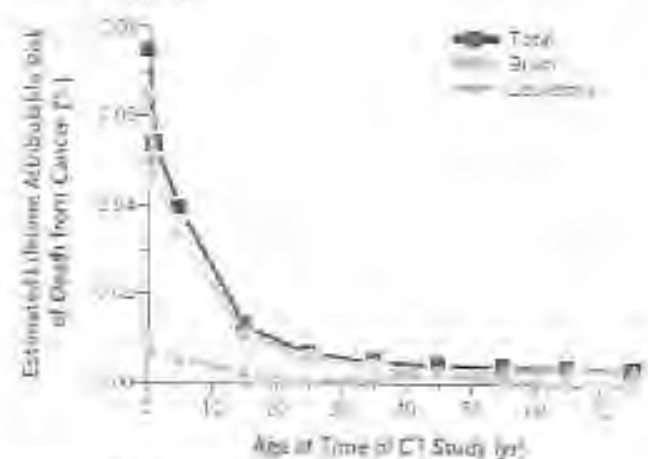

D Aboominal Gi, 220 mik.

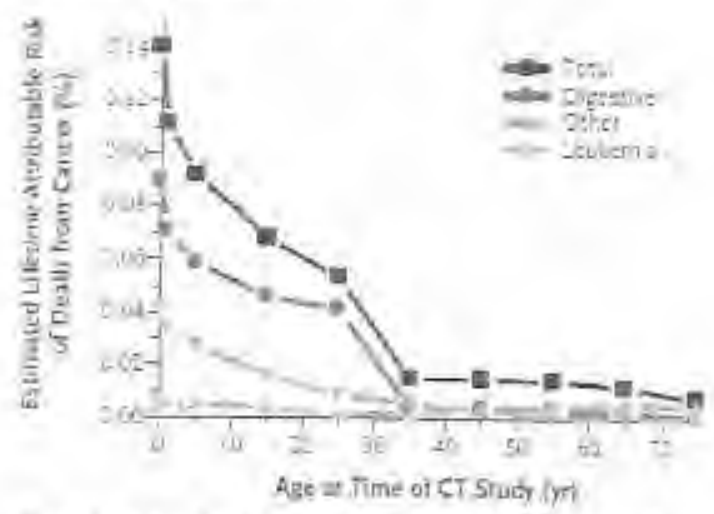

Gambar 4. Perkiraan dosis organ dan risiko kanker sepanjang hidup dari tipikal CT skan tunggal pada kepala dan abdomen ${ }^{[1]}$ 
Meskipun perkiraan risiko mdividual dari tindakan CT skan adalah kecil. perhatian pada risiko dar peningkatan yang cepat dari penggunaan $C T$ skan saat uni berpotensi menjadi isu kesehatan masyarakat pada masa mendatang jika risiko individual yang kecil ini diterapkan páda populasi yang besar yang terus mentingket. Organisasi besar international yang bertanggungjawab terhadap evaluasi efek dan risiko radiast, seperti ICRP. UNSCEAR dan lainnya, sependapat bahwa tcrdapat kemungkinan tidak ada dosis tendah radiasi sebagai batas ambang untuk menginduksi kanker yang berarti tidak ada jumlah radiasi yang dapat dipertimbangkan aman secara absolut. Data dari stadi epidemiologi terakhir pada korban bom atom dan populasi lain yang teriradiasi menunjukkan risiko yang kecil tetapi signifikan peningkatan risiko kanker meskipun pada tingkat radiasi yang rendah yang relevan dengan CT skan pada anak.

Dosis efektif dari sekali skan CT pada anak dapat berkisar dari sekitar $<1$ sampai $30 \mathrm{mSv}$ (Tabel 2)

Tabel 2. Rentany dosis organ dari berbagai jenis pemeriksaan radiologik pada anak

\begin{tabular}{|c|c|c|c|}
\hline $\begin{array}{l}\text { Jeriis } \\
\text { pemeriksaan }\end{array}$ & $\begin{array}{l}\text { Organi } \\
\text { turget }\end{array}$ & $\begin{array}{l}\text { Dosis } \\
\text { Retap } \\
\text { (mGy) }\end{array}$ & $\begin{array}{l}\text { Dosis } \\
\text { etektif } \\
\text { (mSv) }\end{array}$ \\
\hline $\begin{array}{l}\text { Kepala ( } 200 \\
\text { mAs, tanpa } \\
\text { penyesuaian) }\end{array}$ & Orak & $23-49$ & $\begin{array}{l}1,8- \\
3,8\end{array}$ \\
\hline $\begin{array}{l}\text { Kepala (100 } \\
\text { mAs, } \\
\text { disesurikan) }\end{array}$ & Otak & $11-25$ & $\begin{array}{l}0,9 \\
1,9\end{array}$ \\
\hline $\begin{array}{l}\text { Abdomen } \\
(200 \mathrm{mAs} \text {. } \\
\text { tampa } \\
\text { penyesuatian) }\end{array}$ & Lambung & $21-43$ & 11 -24 \\
\hline $\begin{array}{l}\text { Nbdomen ( } 50) \\
\text { miAs. } \\
\text { disesuaikan) }\end{array}$ & Lambung & $5-\pi 1$ & $3-6$ \\
\hline $\begin{array}{l}\text { X-ray dada } \\
\text { posterior } \\
\text { anterior }\end{array}$ & Parc & $\begin{array}{l}0,04- \\
0,08\end{array}-$ & $\begin{array}{l}0.01 \\
0.03\end{array}$ \\
\hline $\begin{array}{l}\text { X-ray dada } \\
\text { lateral }\end{array}$ & Раги & $\begin{array}{l}0,04 \\
0,10\end{array}$ & $\begin{array}{l}0,03- \\
0,06\end{array}-$ \\
\hline
\end{tabular}

Di antara anak-atiak yang meterima lindakan CT skatr. paling tidak sekitar sepertiganya mendapatkan tiga kali skan yang menimbulkan kekawatiran khusus. Sebagai contoh, tiga skan dapat diharapkan berisiko kanker tiga kali dari setiap skan tunggal. Selain itu. selama pemeriksaan unggal mungkin dilaknkan lebil dari satu kali skan yang berari meningkatkan lebih lajuh dosis radiasi. Dengan demikian akan semakin besar masalah pada kesehatan masyarakat jika populasi anak yang terpupar dengan risiko yang kecil ini meningkat terus dengan cepat.

\section{Reduksi Risiko Penggunaan Ct Scan Pada Anak} Keseimbangan antara manfaat dan risiko penggunaan radiodiagnostik selama ini telah terbentak dan dipahami dengan baik tetapi tidak demikian halnya dengan penggunaar CT skan, Jumlah radiasi yang diperlukan untuk pemeriksaan CT pada janin dan anak lebih rendah dari dewasa. Jika seting yang sama digunakan untuk anak dan dewasa, maka anak-anak akan menerima kelebihan jumlah radiasi yang tidak diperlukan.

Beberapa hal yang dapat dilakukan untuk mereduksi lingkat radiasi yang diterima anak dari pemeriksaan dengan CT skau yaitu (1) melakukan penyesuaian terhadap parameter paparan CT skan yang akan digunakan untuk anak berdasarkan ukuran'berat badan anak; (2) pembatasan sekecil mungkin bagian tubuh yang diskan: (3) memperkecil mA dan/atau $\mathrm{kVp}$ menggunakan sering paparan (Tabel 3) disesuaikan untuk anak khususnya untuk skeletal, pencitraan paru dan pemeriksaan follow up; (4) hasil pencitraan untık tujuan diagnostik tidak dengan resolusi tinggi dengan tingkat radiasi yang rendah; (5) mengganti penggunaan CT skan dengan opsi lain seperti USG dan Magnetic Resonance lmaging (MRI), dan yang paling efektif adalah (6) menurunkan jumlah pertieriksaan CT yang diresepkan ${ }^{[39][3] !}$.

Protokol CT skan untuk dewasa umumnya multiple scan pada bagian tubuh yang sama sedangkan untuk anak, sebuah skan tunggal pada bag gran tubuh yang menjadi target biasanya culup untuk keperluan diagnostik. Dari sudut pandang individual, ketika sebuah CT skan dijustifikasi dengan kebutuhan medik, risiko yang terkair relatif kecil dibandingkan dengan informasi diagnostik yang diperoleh. Tetapi, jika benar bahwa sekjtar sepertiga dari semua CI skan tidak dijustifikasi dengan kebutuhan medik, maka sejumlah pasien anak akan diradiasi meskipun tidak diperlakan. 


\section{KESIMPULAN}

Pernanfaatan kecanggifian alat CT skan dalam radiologi diagnostik disertakan dengan penerimaan dosis radiasi yang jauh lebih besar yang mengakibatkan peningkatan nyata terhadap tingkat paparan radiasi pada masyarakat. Peningkatan penggunaan CT skan harus disertakan dengan pemahaman yang baik terkail mantaat dan risiko dalam pengambilan kepuiusan untuk situasi klinik yang sedang dievaluasi meskipun kemungkinati risiko individual terhadap kanker sangat kecil.

Pemeriksaan CT yang dilakukan dengan benar pada anak harus memapari anak dengan paparan radiasi jauh lebih rendah dari prosedor yang sama pada dewasa.

Ketika mengkaji risiko, penting untuk membedakan antara risiko individual dan risiko kolektif kesehatan masyarakat. Meskipun risiko terhadap individual adalah kecil dan dapat diterima untuk pasien simptomatik, tetapi populasi terpapar adalah besar dan terus mengalami peningkatan Bahkan risiko radiasi individual yang kecil, ketika dimultiplikasi dengan sebuah nomor yang besar, maka akan menjadi masalah kesehatan masyarakat jangka pamang yang signifikan yang akan terbukti beberapat tahun kemudian. Ini berarti tanpa disadari sedang menciptakan masalah kesehatan masyarakat di masa depan. Risiko yang diperkirakan terkait dengan CT adalah tidak didasarkan pada model2 atau ekstrapolasi dosis. Tetapi pada laju kanker terkait radiasi yang dikur secura langsung diantara orang dewasa dan anak yang pada masa lali terpapar dengan rentang dosis organ yang sama dengan yang dilepadakan/diperoleh selama studi CT.

Berbagai aplikasi skrining kesehatan yang diusulkan yang berhasis $\mathrm{CT}$ pada populasi asimptomatik adalah belum pada posisi ketika potensi manfaat dapat secara kuantitatif diseimbangkan dengan potensi risiko radiasi. Dialog antara radiologist, dokter gawat darurat. dokter terkait lainnya, pasien dan keluarga sangat diperlukan untuk menciptakan cara praktis dalam memperlambat peningkatan penggunaan CT dan paparan dosis radiasi berlebih pada anak tanpa ada kompromi terhadap pemenuhan perawatan terhadap pasien, adalah tanggungjawab tim medik untuk memastikan bahwa setiap penggunaan $\mathrm{CT}$ scan is indicated. Radiologist harus memastikan bahwa risiko radiasi yang diterima anak akan seminimal mungkin berdasarkan $A x$ Low As Reasonably Achievable (ALARA) dengan menentukan teknik dan protokol yang benar. Informasi dalam makalah ini diharapkan dapat membantu dalam pengambilan keputusan dan diskusi dengan tim medik, pasien dan keluarga.

\section{DAFTAR PUSTAKA}

1. Hall,E,J and Brenner, D. J., Cancer risks from diagnostic radiology. The British Journal of Radiology 81: 362-378, (2008).

2. White, K.S., Helical/spiral CT scanning? a pediatric radiology perspective Pediatr Radiol 26: 5-14, (1996).

3. Linton, O.W. and Metller, F.A. Ir., National conference on dose reduction in CT, with an emphasis on pediatric patienks, $J J R$ Am J Roentgenal 181: 321-9, (2003).

4. Brenner, D.J. and Georgsson, M.A.. Mass screening with CT colonography: should the radiation exposure be of eoncern? Gastroenterology 129: 328-37, (2005).

5. Brenner, D.J. and Elliston, C.D., Estimated radiation risks potentially associated with full-body CT screening, Radiology 232: 735-8, (2004).

6. International Committee on Radiological Protection, Managing ptrient dose in computed tomography, ICRP Publication 87. Elsevier Science; Oxford. UK, (2002).

7. Brenner, D. J. and Hall, E.J., Computed Tomography - An tncreasing Source of Radiation Exposure. The new engl and journal of medicine, 357: 2277-84, (2007).

8. Heiken, J.P., Peterson, C.M., Menias, C.O., Virtual colonoscopy for colorectal cancer screening; current status. Cuncer Imaging 5 Spec No. A: S133-S139, (2005).

9. Henschke, C.1., Yankelevitz, D.F., Libby, D.M., Pasmantier, M.W., Smith, J.P., and Mietinen. O.S., Surviyal of patients with stage I lung cancer detected on CT screening, $N$ Engl f Med 355:1763-71, (2006).

10.Bach, P.B, Jett, J.R., Pastorino, U., Tockman, M.S., Swensen, S.J., and Begg, C.B.. Computed tomography screening and lung cancer outcomes. JAMA 297: 953-61, (2007).

11.Brenner, D.J. Radiation risks potentially associated with low-dose CT screening of adult smokers for ling cancer. Radiology 23I; 440-5, (2004). 
12.Brenner, D.J., and Elliston. C.D., Estimated radiation risks potentially associated with full-body CT screening. Radiology 232: 735-8, (2004).

13. Stephen, A.E., Segev, D.L, and Ryan, D.P., et al. The diagnosis of acute appendicitis in a pediatric population: to CT or not to CT $J$ Pediatr Surg 38:367-71, (2003).

14. Beinfeld, M.T., Wittenberg, E., and Gazelle, G.S., Cost-effectiveness of wholebody CT screening. Radiology 234: 415-22, (2005).

15.McNitt-Gray, M.F. AAPM/RSNA Physics Tutorial for Residents: topics in CT. Radiation dose in CT. Radiograplics 22: $1541-53$, (2002).

16.Paterson, A., Frush, D.P., and Donnelly, L.F., Helical CT of the body are settings adjusted for pediaric patients? AJR Am J Roentgenol 176: 297-301, (2001).

17.Hall, E. I and Graccia. A. J, Radiobiology for the radiologist. $7^{\text {ti }}$ ed, Lippincott Williams \& Wilkins. Philadelphia, USA. (2012).

18.Brenner, D.J., Slowing the Increase in the Population Dose Resulting from CT Scans. Radiation Research 174: 809-815, (2010).

19.International Committee on Radiological Protection, Recomendations of the International Conmission on Radiological Protection, ICRP Publication 26. Pergamon Press, Oxford. UK, (1997).

20.Preston, D.L., Pierce, D.A. and Shimizu, $Y_{\text {. . et al., Fffect of recent changes in atomic }}$ bomb survivor dosimetry on eancer mortality risk estimates. Radial Res 162: $377-89,(2004)$.

21.Preston D.L., Shimizu, Y., Pierce, D.A., Suyama, A., and Mabuchi, K, Studies of mortality of atomic bomb survivors. Report 13. Solid cancer and noncancer disease mortality: 1950-1997. Radiat Res 160: 381407, (2003).

22.Pierce, D.A. and Preston, D.L., Radiationrelated cancer risks at low doses among atomic bomb survivors. Radial Res 154: 178-86, (2000).

23.Preston, D.L., Ron, E., and Tokuoka, S., et al., , Solid cancet incidence in atomic bomb survivors: 1958-1998, Radiat Res 168: 1. 64.

24. National Research Council of the National Academies, Health Risks from Exposure to Low Levels of lonizing Rodiation - BEIR VII. The National Academies Press, Washington, DC, USA, (2006).

25.Cardis, E., Vrijheid, and M., Bletner, M., et al. The 15-country collaborative study of cancer risk among radiation workers in the nuclear industry: estimates of radiationrelated cancer risks. Radiat Res 167: 396-416, (2007).

26.Brenner, D.J., Elliston, C.D., and Hall, E. I. Berdon. W.E., Estimates of the cancer risks from pediatric CI radiation are not merely theoretical. Med Phys 28: 2387-8, (2001).

27. Linton, O.W., and Mettler, F.A. Jr, National conference on dose reduction in $C T$, with an emphasis on pediatric patients. A.JR AM J Roentgenol 181: 321-9. (20013).

28.Paterson, A, Frush, D.P., Donnelly, L.F. Helical CT of the body: are settings adjusted for pediatric patients? A.JR Am .J Roentgenol 176: 297-301, (2001).

29.Arch, M.E., and Frush, D.P., Pediatric body MDCT: A 5-year follow-up survey of scanning parameters used by pediatric radiologists, American Journal of Roentgenology 176:289-296, (2008).

30.McCollough, C.H., Bruesewitz, M.R., Kotler, J.M. Jr., CT dose reduction and dose management tools; overview of available options: Radiographics 26: 503-12, (2006).

31.Semclka, R.C., Armao, D.M., Elias, J. Jr., and Huda, W.. Imaging strategies to teduce the risk of radiation in CT studies, including selective substitution with MRI. I Magn Reson Imaging 25: 900-9, (2007). 